\title{
Inside The National Highway Traffic Safety Administration: Legal Determinants of Bureaucratic Organization and Performance
}

\author{
Jerry L. Mashaw and David L. Harfst $\dagger$
}

\section{INTRODUCTION}

In an earlier article we described how the National Highway Traffic Safety Administration (NHTSA) was established to force the design of safer automobiles through the promulgation of national safety performance standards. ${ }^{1}$ By the mid-1970s, however, it had become a consumer complaint bureau whose massive recall activities had no discernable effect on motor vehicle safety. We attributed NHTSA's shift in regulatory strategy to the external legal culture. In particular, the agency had adjusted to a proceduralized form of judicial review that had burdened, dislocated, and ultimately paralyzed its rule making efforts. By contrast, the judiciary reacted so favorably to NHTSA's recall efforts that manufacturers soon viewed legal resistance to recalls as counterproductive.

Anyone who has a nodding acquaintance with bureaucracies and their internal atmospheres will view this straightforward story of agency adjustment to external legal control with considerable skepticism. Bureaucratic behavior is also determined by internal factors such as office organization, established routines, resource allocations, professional cadres, and unique leaders. To look inside a bureaucracy, moreover, is to explore institutional personality-the sense of mission, morale, indeed the culture, that guides the day to day activities of a bureaucracy's functionaries. Bureaucratic institutions have their own internal laws, expressed both in regulation and in routine.

† Jerry L. Mashaw is the William Nelson Cromwell Professor of Law and Professor, Institute for Social Policy Studies, Yale University. David L. Harfst practices with the firm of Covington and Burling and is a visiting Lecturer in Law at Yale Law School. A different version of this article will appear as Chapter Nine in The Struggle for Auto Safety. (forthcoming, Harvard 1990).

1 Jerry L. Mashaw and David L. Harfst, Regulation and Legal Culture: The Case of Motor Vehicle Safety, 4 Yale J Reg 257 (1987). 
The repercussions within an agency of the legal culture's rejection or validation of the agency's outputs are always uncertain. External legal controllers often cannot know or comprehend an agency's internal laws, not to mention its organizational culture. Yet these internal factors determine the meaning and effect of blunt legal signals such as "affirmed," "reversed," and "remanded." Analysts of the impact of legal commands on agency performance, therefore, often find tales of unexpected consequences, ${ }^{2}$ irony, ${ }^{3}$ and dysfunction. ${ }^{4}$ They sometimes find that the law has no effect at all on bureaucratic behavior. ${ }^{5}$ Indeed, courts frustrated by the ineffectiveness of legal directives often try their own hand at reorienting agencies' internal laws, cultures, and personnel. ${ }^{6}$

Such stories suggest that organizational cultures are internally resilient; that is, that they are highly resistant to external threats and manipulation. Or, perhaps more accurately, these stories suggest that the relatively intractable internal cultures of organizations will divert external controls into bureaucratic channels, or translate them into organizational instructions, that produce results far different from the results intended.

We, too, are fascinated by the tales of illusory, ironic, and unexpected effects of the law's attempts to control administrative action, but our findings concerning the National Highway Traffic Safety Administration are not of that genre. ${ }^{7}$ The external legal culture's ready validation of recalls, combined with its grudging and limited legitimation of rulemaking, operated in the intended directions. Over time the agency reorganized its internal culture to reflect the demands of external legal controllers. While the results are perverse from the standpoint of the safety goals of the 1966

\footnotetext{
${ }^{2}$ See, for example, Jerry L. Mashaw, Bureaucratic Justice 187-88 (Yale, 1983).

${ }^{3}$ See, for example, R. Shep Melnick, Regulation and the Courts 344-45 (Brookings, 1983).

4 See, for example, Ralph K. Winter, Jr., Judicial Review of Agency Decisions: The Labor Board and the Court, $1968 \mathrm{~S} \mathrm{Ct}$ Rev 53.

'See, for example, Jerry L. Mashaw, et al, Social Security Hearings and Appeals 12550 (Lexington, 1978); Martin Shapiro, The Supreme Court and Administrative Agencies 196-200 (Free Press, 1968).

- See Owen M. Fiss and Doug Rendleman, Injunctions (Foundation, 2d ed 1984); Note, Eliminating the Continuing Effects of the Violation: Compensatory Education as a Remedy for Unlawful School Segregation, 97 Yale L J 1173 (1988).

7 Nor are the more general, statistical findings of our colleagues Donald Elliot and Peter Schuck. They report that a large proportion of judicial remands to administrative agencies produce policy changes that the parties seeking judicial review believe to be responsive to their concerns. See Donald Elliott and Peter Schuck, To the Chevron Station: An Empirical Study of Federal Administrative Law, 1990 Duke L J xx (forthcoming June 1990).
} 
Motor Vehicle Safety Act, ${ }^{8}$ the striking feature of the NHTSA story is the extreme malleability of the agency's internal culture. The regulatory activity and organizational change inside NHTSA during the crucial years of its strategic shift from rules to recalls thus suggest the fragility of at least some organizational cultures when pressured, even mildly, by the external legal environment.

\section{Organizational Fate}

In a mid-1970s portrait, ${ }^{9}$ Charles Pruitt described NHTSA as committed to remaking the motor vehicle through the issuance of motor vehicle safety standards. In Pruitt's view, this stance was "an inevitable ... product of the way in which the agency ha[d] been staffed, organized and led."10 At the time of his research, in the mid-1970s, engineers held virtually all key posts in the agency. Its preference for motor vehicle standard-setting over alternative regulatory strategies (for example, highway redesign or the modification of driver behavior) simply reflected "the task [that engineers] do best." "11 Pruitt portrayed NHTSA as an agency that had been "captured" by its safety engineers.

Pruitt's depiction was truly an inside portrait. He relied heavily on the perceptions of personnel within the agency, and there is no reason to believe that his informants were either systematically misled by key agency officials or less than candid about the "feel" of the agency's internal culture. Yet even at the time Pruitt wrote, the agency's rulemaking years were already behind it. Ninety percent of its total rulemaking output occurred prior to $1974 . .^{12}$ Indeed, none of its current safety rules was first issued after 1976. How could an agency organized and staffed as Pruitt describes thereafter fail almost completely to promulgate any new vehicle safety rules?

The answer is that NHTSA had been and was changing rapidly. Michael Finkelstein, Associate Administrator for Rulemaking,

8 The most methodologically sophisticated study of the effects of NHTSA's safety rules estimated that they reduce fatalities and severe injuries by twenty to thirty percent. See Robert W. Crandall, et al, Regulating the Automobile 55, 69 (Brookings, 1986). Recalls, by contrast, have no known effects on motor vehicle safety. See discussion in Mashaw and Harfst, 4 Yale J Reg at 313 (cited in note 1).

- Charles Pruitt, People Doing What They Do Best: The Professional Engineers and NHTSA, 39 Pub Admin Rev 363 (1979).

10 Id at 363 .

11 Id at 370 .

1249 CFR $\$ \S 571.100-571.126,571.200-571.222,571.301-571.302$ (1989); US Dept of Transportation, Motor Vehicle Safety 1978 32-34 (NHTSA annual report). 
indicated how far and how fast the agency had come in a 1980 memorandum to his rulemaking staff, entitled "Why I Am Losing My Hair." "Th That memorandum was pitched in light-hearted tones, but its message was serious and unmistakable: the guard had changed, permanently. Finkelstein got straight to the point:

To insure that intelligent regulations are issued, we must take advantage of all the talent in NHTSA and work with our colleagues, particularly those in OCC [Office of the Chief Counsel] and P \& P [Plans and Programs]. Moreover, neither OCC nor P \& $\mathrm{P}$ are expected to provide automatic endorsements of our work, but must independently examine our proposals ....

Many of you (and I will admit that it hits me occasionally as well) believe that P \& P and OCC exist to harass us. That they are not cooperating to meet deadlines. That they continually raise issues that are without merit or fail to understand our analysis. I don't agree. ${ }^{14}$

After reviewing the situation in detail (Finkelstein described the office as "festering" with an "undercurrent of discontent"), he announced new procedures to force the rulemakers to respond to the objections raised by lawyers and analysts. ${ }^{15}$ Finkelstein then concluded in tones that were both conciliatory and ominous:

I know that it is annoying to see documents that are acceptable to us-or are as good as we can produce under a tight deadline--seemingly being picked to death by others at their leisure.

I do not for a moment believe that we are always wrong and $\mathrm{P} \& \mathrm{P}$ or OCC is always right. However, there is little that we can do to correct them. I think that it will be far more productive to concentrate on eliminating some of the reasons for complaints, warranted or unwarranted. ${ }^{16}$

Finkelstein's memorandum was but one example of the defensive organizational strategy that had given the cost-benefit analysts and lawyers in $\mathrm{P} \& \mathrm{P}$ and OCC as great a role in passing (and stalling) motor vehicle standards as the rulemaking [RM] staff. As the frustrations of Finkelstein's staff attest, that new structure ef-

\footnotetext{
13 Memorandum from Associate Administrator for Rulemaking to All Rulemaking Staff (February 1, 1980) (on file with authors).

14 Id at 1.

15 Id at 3 .

${ }^{16}$ Id at 4.
} 
fectively checked the engineers' rulemaking bias. Indeed, the Finkelstein memo reflected many changes in NHTSA's internal processes and personnel over the decade of the 1970s-changes that had transformed the agency's internal power structure. Within those ten years the engineering-rulemaking dominance that Pruitt identified gave way to a lawyer/economist-recall dominance.

Putting the story this boldly suggests that professional warfare within NHTSA caused the shift from rules to recalls. From the inside, it may have looked that way. The professional culture of the engineers did clash with that of the lawyers and economists, and professional orientation may have motivated or guided the combatants. Yet this is an enormously incomplete account of why the agency's regulatory technique changed. For we need to know not only that lawyers and economists were in conflict with engineers-a conflict that may have been a natural outgrowth of their differing professional orientations-but also why the former groups seem to have triumphed. Even if we know that professional orientation "drove" or motivated the actors, we still need to explain why the economists and lawyers were ultimately successful. What were the rules that governed the competition? And how did those rules-reflected in the agency's staffing and organization-emerge?

Our thesis, of course, is that the environment, particularly the legal culture, selects the winner in a struggle for survival or preeminence. Lawyers and economists are not inherently better endowed than engineers for survival or preeminence in regulatory settings. Indeed, when safety engineering is the job at hand, one would imagine just the opposite to be true. Nor were other factors that promote organizational success-agency structure, decision routines, or budgetary resources-fixed during NHTSA's early years in ways that systematically disadvantaged the engineers. Indeed, quite the contrary. Otherwise Pruitt's finding of the initial preeminence of engineers would have been inconceivable.

Something in the agency's regulatory environment must have exalted one group over the other. Recognizing, of course, that this preeminence may have been reflected, strengthened, and, in the short run, maintained, by resource allocations and structural features within and controlled by the agency, we believe that "something" to be the law.

We are not saying that this shift in regulatory tactics can be explained simply as the result of interaction between professional culture and legal constraint. Indeed, put this way, "professional culture" and "legal constraint" are caricatures. At the very least, a professional's moral commitments, individual personality, and or- 
ganizational role shape his conduct. To know that a person is a lawyer or an economist is not to predict his behavior. And the dictates of the law or legal culture are not translated immutably into the bureaucratic constraints and empowerments that actually determine an actor's success.

It is therefore both fundamentally correct and hopelessly incomplete to say that NHTSA's shift from rules to recalls signalled the triumph of lawyers and economists over safety engineers in a multi-year struggle mediated by the external legal culture's evaluation of their respective efforts. Professional cultures, bureaucratic roles, individual personalities, agency structures and decision processes, judicial review, congressional oversight, amendment of statutes and regulations, appropriations, executive branch requirements, and a host of other factors (including chance) contributed to that ultimate result. Yet a more detailed look at the events inside NHTSA during the 1970s reveals the singular importance of the law in empowering bureaucratic actors and establishing NHTSA's internal standards of success and failure.

\section{ENGINEers IN CONTROL}

\section{A. The Rise of the Office of Motor Vehicle Programs (MVP)}

In 1971, Robert Lee Carter, age forty-four, became acting Associate Administrator for Motor Vehicle Programs. Carter's professional background perfectly suited him to the task of managing the auto safety program that Congress had envisioned in 1966. He had done postgraduate work in human factors engineering at Ohio State University from 1951 to 1953, and worked on aeronautical crashworthiness programs at North American Rockwell for more than a decade. He joined the agency in 1967, as Director of Crash Survivability Research, and in that capacity developed an early and passionate commitment to the airbag.

In many respects, the then-administrator, Douglas Toms, was Carter's perfect foil. Toms knew relatively little about automotive engineering and seemed more comfortable with the Highway Safety Act side of NHTSA's operations. He was delighted to delegate responsibility to his deputies. Indeed, delegation soon became a matter of necessity, as his frequent visits to regional offices, attendance at conferences on auto safety, and other out-of-town engagements earned Toms a reputation as Administrator-inAbsentia.

Carter, an ambitious, tough-minded manager with shrewd bureaucratic instincts and little tolerance for sharing power, set about 
the task of filling this void. One agency colleague remembered Carter as "very dominating," a figure who "controlled information" and "couldn't tolerate disagreement." Another senior staffer stated simply that "you either got along with Bob or you were not there."

The spare administrative structure at NHTSA favored Carter's ascendancy. The agency's few divisions-Motor Vehicle Programs (MVP), Research and Development (R \& D), and Transportation Safety Programs (TSP) - and congressional limits on hiring supergrade personnel meant that Carter had few rivals inside the agency to challenge his control over both the rulemaking and recall programs. Carter's authority was formalized in November 1972 by an internal directive, the 800-1 Order, ${ }^{18}$ which vested virtually all important rulemaking activities in MVP. Under Order 800-1, MVP had initial responsibility for analyzing not only engineering aspects of the rules, but also production lead times and economic impacts, costs and benefits, expected industry and public reaction-even legal and political issues. MVP had ultimate decisional authority as well. After MVP engineers prepared a "preliminary review paper" summarizing a proposed action, other offices could only "comment" on the proposal within a strict timetable. The 800-1 Order gave MVP explicit authority to adopt or reject the comments of other offices when seeking the Administrator's "concurrence" to initiate rulemaking.

Once a decision was made to go forward with a rule, the proposal had to survive review by an evaluation panel. But MVP prepared the technical documents for the panel, such as the "engineering position paper," and, although composed of representatives from all of NHTSA's major organizational elements, seven of the thirteen review panel members were from MVP. An MVP representative served as chair.

The 800-1 Order was more than a statement of aspirations. It implemented a regulatory process that was in fact tightly controlled by the engineers within NHTSA. Carter and his colleagues in MVP determined which rulemaking initiatives would go forward and which would not. Carter's top priority was Standard 208, which would require occupant passive restraint systems, airbags in particular; that rulemaking effort consumed the lion's share of

\footnotetext{
17 The authors interviewed approximately forty current or former agency officials between December 1980 and June 1987. Notes and other interview materials are on file with the authors.

18 NHTSA, Order 800-1 (November 7, 1972) (on file with authors).
} 
agency resources. Inside NHTSA, some murmured that MVP's commitment to the airbag was beginning to resemble a crusade. Carter was nicknamed "Associate Administrator for MVSS [Motor Vehicle Safety Standard] 208," and critics claimed that Carter had lured Administrator Toms into thinking that the airbag would "make him famous." Even strong safety advocates, such as Ralph Nader, complained that NHTSA was losing its perspective on passive restraints, and that it was neglecting or compromising on recalls to secure manufacturer cooperation on Standard $208 .^{20}$ This emphasis seemed unlikely to change. In October 1971, MVP released a general Rulemaking Plan whose central feature was the integration of most safety rules into a single crashworthiness superstandard, built around Standard 208.

Early engineering dominance thus comports with Pruitt's findings. But Pruitt failed to note the close alignment between the engineers' professional culture and legislative intent. The engineers' preference for imposing technology-forcing safety standards conformed with the congressional vision of NHTSA as an expert agency guided by the new science of accidents. The legislative history of the Motor Vehicle Safety Act indicated strong congressional support for the use of "passive" public health interventions, such as the airbag. ${ }^{21}$ Carter's professional preoccupation focused on precisely the kind of device that Congress had in mind when it revolutionized the national approach to motor vehicle safety. If engineers had "captured" NHTSA for the purpose of promoting such devices, it was Congress that had ordered the assault. ${ }^{22}$

Pruitt's sketch, however, missed an even more important dimension of life inside the agency. He portrayed engineers as part of a "homogeneous" community whose shared norms bound members to a common course of action, whatever their organizational affiliation within the agency. Somehow, Pruitt overlooked the

19 Personal interview with Frank Berndt (June 2, 1987).

${ }^{20}$ Nominations-June, Hearings Before the Senate Committee on Commerce, John W. Snow, to be Administrator, NHTSA, 94th Cong, 2d Sess 85 (1976) ("Snow Nomination Hearings") (Nader criticizing Administrator Toms for having "put all his eggs in one basket here, the air bag, and avoided paying much attention to other safety standards").

${ }^{21}$ National Traffic and Motor Vehicle Safety Act of 1966, 15 USC §§ 1381-1431 (1982 \& Supp 1989). See, for example, HR Rep No 1776, 89th Cong, 2d Sess 10 (1966) (urging adoption of measures to make motor vehicles more crashworthy); and 5 Rep No 1301, 89th Cong, 2d Sess 3 (1966) (citing "Graphic Evidence" that vehicle interiors can be reconfigured to enhance occupant protection).

${ }^{22}$ For a critique of Pruitt's analysis, see Leon S. Robertson, The National Highway Traffic Safety Administration: Evidence Contrary to Pruitt's Characterizations, 40 Pub Admin Rev 294 (1980). 
abundant evidence that different groups of engineers were, in fact, at war with each other, and that conflict along internal organizational lines hampered the issuance of innovative safety rules. Increasingly, that conflict explained the gulf between Carter's state of the art aspirations and the mundane reality of NHTSA's actual rules.

B. MVP vs. $R \& D$

Gene Mannella, age forty-one, joined NHTSA in late 1972 as Associate Administrator for R \& D. His prior career included positions as Director of Technology at NASA's Electronics Research Center and Dean of the School of Architecture and Engineering at Catholic University. He found that NHTSA was a "rudderless" agency and that the $R \& D$ Office in particular was in a "state of disarray." ${ }^{23}$ He perceived only one genuine leader at NHTSA: Bob Carter. MVP was a "well-knit organization" with an extensive and vigorous external constituency: private companies seeking to market the airbag, the insurance industry, Nader's public interest groups, and Senator Hartke (One of the earliest and most ardent supporters of the auto safety program in congress) and his staff, among others. No other division within the agency enjoyed such support, and Carter adroitly used his contacts outside NHTSA to preserve and extend his authority within. Mannella was impressed that only Carter seemed to know what would happen at the increasingly frequent and contentious congressional hearings, and accordingly, that only he knew how to prepare for them.

Despite this unsettling state of affairs, Mannella found that he had arrived at an auspicious time. Belatedly fulfilling Congress's commitment to provide NHTSA with a research arm, the appropriations committees were hurling bodies and dollars at the R \& D Office, ${ }^{24}$ while growth in the other agency divisions stood still. Congress clearly wanted the research office to play a more important role.

But $R$ \& D's influence was not likely to increase unopposed. Tension had been building within NHTSA for months over the control of the research program, and with Mannella's arrival, this struggle burst into open and prolonged conflict. The central issue was whether MVP had veto power over research projects and had

\footnotetext{
${ }^{23}$ Personal interview with Gene G. Mannella (June 19, 1987).

24 See, for example, US Dept of Transportation, Motor Vehicle Safety 1980 Appendix B (NHTSA annual report) (showing increase in personal strengths allocated to research and analysis from 118 in Fiscal Year 1971 to 174 in Fiscal Year 1972).
} 
to "sign off" on proposed R \& D programs. The battle lines were clearly drawn. Carter considered research to be a rulemaking support function; R \& D was to act as an adjunct of MVP. Mannella strongly disagreed. He believed that the $\mathrm{R} \& \mathrm{D}$ Office had to be autonomous in order to independently appraise auto safety programs.

Three circuit courts of appeals issued decisions in 1972 supporting Mannella's position. In each case, the circuit court sent the agency back to the drawing board to further research and develop its proposals. ${ }^{25}$ The courts' displeasure with NHTSA's work product suggested that the agency had failed to undertake adequate, objective technological scrutiny, and that rulemakings needed to be supported by independent appraisals of research. ${ }^{26}$ The agency's position in court would be strengthened by independent appraisal of research providing the empirical basis for particular regulations. Carter was surely correct that the $R \& D$ program was meant to support rulemaking. But an organizational form that made $R \& D$ subservient to the rulemaking organization would not promote the agency's goal of effective safety regulation. As Mannella argued, MVP needed to be protected from its own enthusiasm. Both sides had good points. The result was organizational stalemate.

As the months wore on, reports of trench warfare inside NHTSA filtered to the congressional committees. At Senate oversight hearings in 1972, officials of the Public Interest Research Group (Clarence Ditlow and Carl Nash) reported that safety standards seemed to be "almost completely devoid of input from NHTSA's Research Institute (an arm of the research office) which has spent tens of millions of dollars on motor vehicle research and the experimental safety vehicle program." "[O]ne gets the distinct impression when one looks at new proposed rulemaking," Nash continued, "that nobody at NHTSA who is involved in the promulgation of standards actually reviews the research that has been done by the agency." 28

${ }^{25}$ The cases were $H \& H$ Tire Co. $v$ Dept. of Transportation, 471 F2d 350 (7th Cir 1972); Chrysler Corp. $v$ Dept. of Transportation, 472 F2d 659 (6th Cir 1972); and Wagner Electric Corp. v Volpe, 466 F2d 1013 (3d Cir 1972). For an extended discussion of these cases, see Mashaw and Harfst, 4 Yale J Reg at 279-86 (cited in note 1).

${ }^{26}$ Indeed, these decisions were so interpreted by the agency. See Motor Vehicle Safety Oversight, Hearings Before the Senate Committee on Commerce, 93d Cong, 2d Sess 84, 10910 (1974) (statement of Lawrence Schneider, Chief Counsel, NHTSA).

${ }_{27}$ National Traffic and Motor Vehicle Safety Authorization Act of 1972, Hearings on S 3474 Before the Senate Committee on Commerce, 92d Cong, 2d Sess 69 (1972) ("Hearings on S $3474 ")$.

${ }^{28}$ Id at 72 . 
In January 1973, Senator Magnuson, Chairman of the Commerce Committee, demanded an investigation. The General Accounting Office (GAO) issued its report fifteen months later. ${ }^{29}$ In part, the GAO reported, the breakdown between the offices stemmed from the different professional orientations of the two sides. Researchers approached projects "analytically," "whereas the MVP office believed that sufficient analytical data was available to develop structures for testing and thereby start with a more advanced phase of research." ${ }^{30}$ Rulemakers were driven by schedules and were impatient with vague research findings that generated further questions and delayed regulatory implementation. Consequently, they tended to ignore $R \& D$ reports. Researchers, by contrast, were free of deadline pressures and tended to adopt the ethic of the independent research contractors' employees, with whom they had more frequent contact and who shared their joy of research for its own sake. Indeed, NHTSA's reliance on contract research greatly magnified its problems. After reviewing a sample of twelve research projects under contract, GAO reported that "[m]ost of the contractors' final reports included a recommendation that further work be done to confirm research conclusions."31

According to the picture painted by GAO, rulemakers were lucky to get any research done on their priority initiatives. Ineffective communication and professional and personal preferences sent researchers on frolics of their own that seemed to lead anywhere but the rulemaking docket. No one, it seemed, insisted on coordination. The researchers were never satisfied; the rulemakers lacked sufficient data to withstand judicial review. Regulation stagnated.

\section{Opening the Complaints Bureau}

As rulemaking conflict continued both inside and outside the agency, the Toms era at NHTSA drew to a close. On March 30, 1973, his last day in office, Toms granted an interview to the New York Times to review his accomplishments and "wax nostalgic." 32 Toms was proudest, he said, of the creation of NHTSA as a separate agency, which had given regulators "the independence to deal with Congress and the lobby groups" and was "his most significant

29 General Accounting Office, Improvements Needed in Planning and Using Motor Vehicle Safety Research (September 16, 1974).

${ }^{30}$ Id.

31 Id.

32 Departing Traffic Safety Chief Says It's Hard to Find Successor in "Hot Seat," NY Times 29 (April 2, 1973). 
achievement on behalf of traffic safety." ${ }^{33}$ Knowledgeable readers of the Times report were puzzled by this claim. NHTSA's separation from the Federal Highway Administration had been planned long before Toms's arrival, and the basic organization of the agency had changed very little under his supervision. During his tenure, however, one box was added to the organizational chart that represented a genuine innovation. The Office of Consumer Affairs and Public Information was created to handle consumer inquiries that were flooding the agency. Under Toms, NHTSA took the first steps toward reconstituting itself as a complaints bureau.

Toms had repeatedly testified to Congress that the lines outside his office were growing alarmingly long. ${ }^{34}$ The agency seemed to get no respite from the swarm of angry consumers who demanded its help in repairing their broken cars. The market in safety defect letters was bullish. In 1970, NHTSA received about 5,000 complaints concerning defective automobiles. The following year, the number doubled. The next year, it nearly doubled again. Complaints poured in, not only from individual consumers, but from insurance companies, Congress, consumer groups, other agencies, and NHTSA's own regional offices. It soon became clear that the defects operation must be expanded if NHTSA were to have any hope of answering its mail.

The defects office had been established within MVP in late 1967 as a tiny division of the larger Office of Compliance, whose principal purpose was to enforce safety standards. Initially, the division was staffed by only three professionals. Toms, responding to the flood of incoming mail and to complaints from Congress and Nader that recall investigations were taking too long, increased the staff to thirteen engineers and technicians by the end of 1970 . When the demands on the division did not abate, he retrained additional staff and gave new organizational stature to the recall effort. Effective July 1, 1971, the division was removed from the Office of Standards Enforcement and raised to the status of a separate office, the Office of Defects Investigation (ODI), within MVP. By this time, it had a professional staff of 24, about half the number of professionals in MVP's rulemaking branches.

If rulemaking was a source of internal stress, recalls were an administrator's delight. To a large extent, defect investigations ran

33 Id.

34 Department of Transportation and Related Agencies Appropriations for Fiscal Year 1972, Hearings Before a Subcommittee of the House Appropriations Committee, 92d Cong, 1st Sess, Part 3 at 76 (1971). 
themselves. A study by the staff of the National Product Safety Commission called the process "largely passive." 35 Investigations proceeded then, as now, through three basic phases: preliminary inquiry; engineering analysis; and formal investigation. At each step, the regulatory burdens on NHTSA were much lighter than those of rulemaking. As one Administrator later remarked "There was no lack [of] finding [defects] in my term, I mean, they just came and presented themselves to me." ${ }^{\prime 36}$

NHTSA's senior managers were troubled by one issue, however, as they transferred personnel and funds to ODI in the early 1970s. The agency could not demonstrate any safety benefits from the recall program, and repeatedly told Congress so. Administrator Toms, for example, testified in 1972 that he did not "feel the payoffs [were] high there." ${ }^{37}$ Appearing before the House Appropriations Committee later that year, Toms reiterated that:

We have always said that we should do what we can to be sure that the vehicles on the road were safe. We don't want to contribute to a situation where there are defective parts on cars that could injure or kill people. In the actual analysis of different programs, [however,] the whole defect situation of recalling cars does not have the kind of [safety] payoff that crash survivability of structures has. ${ }^{38}$

Toms's critique was understated, to say the least. Many inside NHTSA, especially in MVP, believed that shutting down ODI would not be a great loss. Robert Lee Carter was foremost among them.

D. OCC vs. MVP: The Engineers' Grip Loosens

On Friday afternoon, July 12, 1974, Larry Schneider, NHTSA's Chief Counsel, suffered a fatal heart attack while playing tennis at East Potomac Park. His death came as a shock to colleagues in the agency. Schneider was only thirty-six, but he had become an instrumental figure at the agency, especially in the af-

ss Staff of the National Commission on Product Safety, Federal Consumer Safety Legislation: A Study of the Scope and Adequacy of the Automobile Safety, Flammable Fabrics, Toys, and Hazardous Substances Programs 76 (GPO, 1970).

${ }^{36}$ Remarks of Joan Claybrook, Yale Law School Seminar on Automobile Safety (April 9,1984 ) (transcript on file with authors).

37 Hearings on S 3474 at 47 (cited in note 27).

3* Department of Transportation and Related Agencies Appropriations for Fiscal Year 1973, Hearings Before a Subcommittee of the House Appropriations Committee, 92d Cong, 2d Sess, Part 1943 (1972). 
termath of the 1974 recall amendments, which greatly increased the agency's investigatory powers and provided for increased fines and penalties against manufacturers. Schneider had personally steered the bill through Congress and was eulogized by Senator Magnuson as a "moving force in legislation to strengthen the auto safety recall provisions." 39 Moreover, because Schneider took a cautious legal position on rulemaking, ${ }^{40}$ his career as Chief Counsel seemed to epitomize a new and more "successful" direction at the agency.

Inside NHTSA, the legal staff had won significant gains in prestige and influence during the years that Schneider had presided as Chief Counsel. Between 1971 and 1974, the workload of the Office of the Chief Counsel (OCC) had tripled, partly because of the "phenomenal" increase in litigation." The Chief Counsel became the number two man-behind the Deputy Administrator-in the Administrator's absence. Indeed, in three years, OCC had leapfrogged every other office in the agency hierarchy. ${ }^{42}$

The ultimate choice for Schneider's successor, Frank Berndt, reflected the repositioning of the agency to take up the enforcement tasks set out in the 1974 recall amendments. The new Chief Counsel had been NHTSA's first enforcement attorney and its most ardent internal advocate for an aggressive recall program. For Bob Carter, Berndt's appointment was hardly welcome news. Tension between Carter and Berndt had long existed concerning the direction, importance, and control of recalls. Berndt had continually pressed Schneider to convince the Administrator to tighten OCC control over defect investigations. It now appeared that Berndt would be in a position to lobby even more aggressively for this control. To Carter, Berndt was a recall "zealot," relentlessly promoting a recall program whose effects were superfluous at best. ${ }^{43}$

Berndt, in turn, regarded Carter as a devious autocrat who "wanted to control everything" and did not take the enforcement

39 Morton Mintz, Safety Advocate Won Cases Against Car Makers, Wash Post D4 (July 13, 1974).

to See note 26.

11 Department of Transportation and Related Agencies Appropriations for 1974, Hearings Before a Subcommittee of the House Appropriations Committee, 93d Cong, 1st Sess, Part 3174 (1973) (statement of Chief Counsel Schneider).

12 Compare 49 CFR $\S 501.4$ (1972) (naming Chief Counsel seventh official in line of succession) with 49 CFR $\$ 501.4$ (1974) (naming Chief Counsel second in line of succession).

${ }^{43}$ Personal Interview with Robert L. Carter (June 9, 1987). 
program "seriously." ${ }_{44}$ Berndt believed that Carter was sacrificing recalls to Standard 208, and was furious that Carter had placed the Office of Defects Investigations under the control of a supervisor (Andrew "No Defect" Detrick, as he was known in OCC) who "didn't really believe in the program." Berndt believed that the engineers and technicians in ODI "didn't know how to investigate cases" and had "pro-industry" leanings.

As the 1970s wore on, the bickering between lawyers and engineers grew steadily worse during the panel meetings that were held to determine whether an "engineering analysis" should proceed to a full-fledged investigation of a defect. The lawyers felt that the engineers in ODI were not sufficiently zealous or competent. The engineers in ODI felt that the lawyers did not understand engineering problems. Berndt and his deputies usually wanted to go forward with investigations. The engineers were more "conservative" and often favored closing the file. They reasoned that if NHTSA had no data establishing that injuries or deaths had occurred (as was often the case), the agency should not press for a recall simply because there were a large number of failures in a vehicle component. After all, the statute only provided for recalls to remedy defects that presented an "unreasonable risk" of injury. ${ }^{45}$

The lawyers were contemptuous of this position. Berndt believed the issue was whether NHTSA could win in court. The statute did not require NHTSA to prove that deaths and injuries had occurred or would occur and Berndt was determined that the agency not take upon itself such an onerous burden of proof. The long line of losses in rulemaking cases showed where that would lead. Berndt refused even to issue a regulatory definition of the term "defect" on the ground that "the relatively broad definition of defect contained in the Safety Act is best suited to the wide variety of defective conditions that may arise."46 The 1966 Act's definition, however, was little more than a tautology: "[d]efect includes any defect in performance, construction, components, or materials in motor vehicles or motor vehicle equipment." ${ }^{47}$ The agency's refusal to provide a more meaningful standard thus allowed it to maintain maximum strategic flexibility.

\footnotetext{
4 Personal interview with Frank Berndt (June 4, 1987).

is 15 USC \& 1391.

16 National Highway Traffic Safety Administration, Response to Petitions for Reconsideration of Defect Notification Regulations, 38 Fed Reg 9509, 9510 (April 17, 1973).

1715 USC \& 1391.
} 
Of course, an operational definition was necessary for decisionmaking purposes. Berndt discussed the matter with colleagues, including a former employee of the Antitrust Division of the Justice Department. These discussions led Berndt to conclude that, under the statute, any malfunction of a safety-related component (for example, wheels, brakes, or lights) could be treated as a defect "per se," much as certain practices, like price fixing, are deemed anticompetitive under antitrust law without a showing of actual harm to competitors. Berndt believed that if the agency could establish that a safety-related component failed in a "disproportionate" number of cars, the burden of proof should shift to the manufacturer to show that accident or injury would not result. ${ }^{48}$

Carter and Berndt were speaking different languages, and neither showed any interest in gaining fluency in the idiom of the other. By late 1973, Carter had grown weary of the feud with Berndt over recall policy. To break the impasse, Carter expressed a willingness to litigate test cases in order to resolve intra-agency differences through judicial clarification of the statute. The courts responded between 1975 and $1977 . .^{49}$ Berndt's per se theory triumphed to a degree that may have exceeded even his expectations. The courts ruled that recalls could be ordered on the basis of evidence that would have been laughed out of court if offered as support for a motor vehicle standard. The recall program was a legal success story, whereas rulemaking had been largely a legal fiasco.

\section{Gregory Takes Charge}

James B. Gregory was Administrator during the crucial years of OCC/MVP competition. Beyond being a licensed driver, Gregory, age forty-eight, had no identifiable ties with auto safety. He was exceedingly uncomfortable with the feuding among the senior staff, but, lacking substantive background, avoided deciding between the contestants. Indeed, rather than resolving the CarterMannella conflict, Gregory institutionalized it. Weary of a decisionmaking process that produced much information but few decisions, Gregory determined in 1974 to resolve the deadlock by transferring the research office to MVP. Associate Administrator Mannella promptly threatened to resign. The Administrator dropped the plan.

\footnotetext{
${ }^{48}$ Briefing Materials, Prepared by NHTSA Office of Chief counsel (undated) (on file with authors).

49 See Mashaw and Harfst, 4 Yale $J$ Reg at 299-302 (cited in note 1).
} 
Instead, minor procedural and organizational changes were adopted that required MVP and R \& D to "concur" in research plans. The goal was to force reconciliation within a fixed timetable and refer irreconcilable differences to the Administrator for resolution. The new procedures produced much referral and little reconciliation. Caught between senior advisors at war among themselves, and buffeted on all sides by the conflicting demands of auto manufacturers, consumer groups, their respective allies in Congress, and others, Gregory groped for a course that would find "public acceptance." But this quest sent Gregory down a lonely, treacherous path that led, ultimately, to his resignation.

\section{A. Standard 208}

Many of the technical uncertainties surrounding the airbag were resolved well before or during the early part of Gregory's term in office. In the months following the Sixth Circuit's 1972 rejection of the first airbag rule, ${ }^{50}$ NHTSA and its contractors watched attentively as a series of vehicles occupied by baboons, cadavers, and instrumented mannequins smashed into fixed barriers at various speeds. The test results made it reasonably clear that the most frequently voiced technical objections to the airbag-danger to out-of-position occupants, inadvertent actuation, toxicity of the propellent, and the like-did not warrant serious concern. Most observers agreed: the airbag worked. ${ }^{51}$

The focus shifted to the costs and benefits of airbags. The agency's own figures indicated that full front seat protection from airbags would save $\$ 4.4$ billion annually in auto accident expenditures, and that the benefits could exceed the costs by more than two to one. ${ }^{52}$ But Gregory was leery. The manufacturers, of course, had produced quite different cost-benefit figures.

More important, the mail from angry ignition interlock customers had poured into NHTSA during Gregory's first days in office and convinced him, as he later said, that there was something uniquely "personal" about auto safety regulation. ${ }^{63}$ Would "rational" consumers be willing to pay the incremental costs of full

${ }^{\text {so }}$ Chrysler Corp. v DOT, 472 F2d 659.

s1 Id. authors).

${ }^{52}$ Untitled and Undated Memorandum by Administrator James Gregory (on file with

ss Regulatory Reform-Vol 4, Hearings before the Subcommittee on Oversight and Investigations of the House Committee on Interstate and Foreign Commerce, 94th Cong, 2d Sess 363-64 (1976). See text at note 59-60 for discussion of the ignition interlock episode. 
airbag protection? Gregory was not sure. Although the airbag controversy had been thoroughly aired in the press and had aroused much interest, the absence of support from individual consumers made the Administrator edgy. Testifying before Congress in 1976, Gregory remarked that he had "not yet received one letter that [he could] think of, from an individual citizen who thinks much of the airbag. ${ }^{5}{ }^{3} \mathrm{He}$ told Congress that "[m]any good ideas, if not thoroughly looked at, and thoroughly planned, can be shot down through lack of public acceptance" and that "public involvement and acceptance ... is something that we must keep in mind during the preparation for new programs, or we will not succeed."s5

These were not necessarily the statements of a timid or indecisive administrator. Events following the 1972 Chrysler decision, ${ }^{56}$ which invalidated major portions of the agency's passive restraints rule, had enshrined "public acceptance" as a legal criterion for NHTSA's standard-setting, both as a practical and a formal matter. In Chry'sler, the Sixth Circuit remanded certain of the passive restraint requirements of Standard 208 for the development of "objective" criteria against which to measure compliance with those requirements. But the remand did not invalidate all of Standard 208. In effect, it left one compliance option, which thus became mandatory-connecting existing seat and shoulder belts to an ignition interlock that would prevent drivers from starting their cars unless their seatbelts were engaged. This device was not only feasible with existing technology, it was cheap. It promised a massive increase in seatbelt usage at virtually no increase in financial cost. The interlock requirement therefore remained in effect pending revision of Standard 208's passive restraints requirement. ${ }^{57}$

The interlock did not survive long in the marketplace, however. First attached to model year 1974 vehicles, the interlocks generated hate mail to Congress reminiscent of the deluge following Richard Nixon's removal of Archibald Cox as Special Prosecutor. By August 1974, Congress had repealed the interlock requirement, forbidden its readoption, and attached a legislative veto to any reissuance of Standard $208 .{ }^{58}$ Moreover, NHTSA's own studies revealed that within nine months of the first appearance of the in-

34 Id at $465-66$.

ss Id at 466 .

s6 Chrysler Corp. v DOT, 472 F2d 659.

3: The interlock even survived judicial review. Ford Motor Co. $v$ NHTSA, 473 F2d 1241 (6th Cir 1973).

ss Motor Vehicle and Schoolbus Safety Amendments of 1974, $\$ 109$ Pub L No 93-492, 88 Stat $1470,1482-83$ (1974), codified as amended at 15 USC $\$ 1410$ (b) (1982). 
terlock in American automobiles, nearly half of them had been "illegally" disconnected. "Public acceptance" thus had both a technological and a political component. Consumers could defeat safety rules with either screwdrivers or political mobilization. While disarming airbag sensors might be beyond the mechanical expertise of most motorists, consumers could induce a congressional veto of revised Standard 208 with postcards.

To gauge public sentiment on the airbag and break the deadlock inside NHTSA, Gregory convened a public hearing on May 23,1975 . The Administrator had promised to issue a final rule that year and the large turnout reflected the participants' concern that this could be their last opportunity to influence the outcome. More than 300 people milled about the hearing room. Some fifty speakers, representing the automotive industry, insurance companies, equipment suppliers, consumer groups, and public and political sectors expressed their views-views that staked out every conceivable position on the issue.

The contradictory testimony at the May hearing obviously did not provide a way out of the impasse inside NHTSA, and Gregory soon despaired of finding a consensus outside the agency. "[I]n a regulating area such as ours," he later said, "there is no 51 percent majority. As a matter of fact, if I get $12 \frac{1 / 2}{2}$ percent, I consider it a landslide." ${ }^{59}$ The Administrator had to choose between the factions. As one agency insider later described it, an "anguished" Gregory closeted himself in his office to fashion a recommendation to the Secretary. ${ }^{60}$

He had reason to be apprehensive. The long-awaited (indeed, overdue) decision was almost certain to stir controversy. Also, the recipient of the action memorandum, the Secretary of Transportation, would not be Gregory's personal friend, Claude Brinegar, but a recent arrival: William T. Coleman. Coleman, a fifty-four year old Philadelphia lawyer, long-time Republican party regular, and civil rights activist, was Harvard-trained and had a recognized expertise in transportation law. To Gregory, Coleman was another unknown variable in the Standard 208 equation.

Gregory's action memorandum refiected his uncertainty. He urged the agency to simultaneously issue two Notices of Proposed Rulemaking (NPRMs). The first would have promulgated a Standard under the Highway Safety Act, requiring the states to take

\footnotetext{
58 Regulatory Reform Hearings at 433 (cited in note 53).

Bo Personal interview with Howard Dugoff, Deputy Administrator under Claybrook (June 12,1987).
} 
whatever measures were necessary-for example, mandatory seat belt use laws (MULs) - to bring seat belt usage to seventy-five percent by January 1, 1980. The second notice would have amended Standard 208 to require driver passive restraints by September 1, 1979 and full front passive protection two years later. Gregory argued that time was of the essence and that the notices should be issued no later than May 1976.

The decision to make two recommendations was strategic. Either proposal might run into a political buzz saw and both proposals would have to undergo congressional review pursuant to the 1974 Amendments. Indeed, in Gregory's view, that was the beauty of his proposal, which would resolve the enigma of public acceptance. ${ }^{61}$ In effect, Gregory urged Secretary Coleman to put the gun to Congress's head. Congress would be forced to decide what the public really wanted.

The Secretary and his senior advisors were not impressed. Some twenty state legislatures had considered but failed to pass mandatory use legislation, and a proposal was pending in Congress to rescind NHTSA's authority to impose sanctions on states that failed to observe the agency's motorcycle helmet traffic safety standard. Would Congress behave any differently if NHTSA tried to force reluctant states to pass MULs? Moreover, the Transportation Department was concerned that the general public would be enraged by mandatory passive restraints. Because of these concerns, the Assistant Secretary for Systems Development and Technology sent a memorandum to Secretary Coleman, dated February 26, urging strong opposition to any passive restraint requirement "at this time."62 The Gregory Proposal was subsequently abandoned.

\section{B. Standard 121}

Gregory was equally frustrated with another rulemaking effort-that surrounding Standard 121, the large truck braking standard. The battle over Standard 121 further illustrates NHTSA's problems with rulemaking and "public acceptance."

${ }^{61}$ Untitled and Undated Memorandum by Administrator James Gregory (on file with authors).

${ }^{62}$ For an account of NHTSA's handling of Standard 208 from 1969 to 1979, see National Transportation Safety Board, Safety Effectiveness Evaluation of the National Highway Traffic Safety Administration's Rulemaking Process, Vol 2: Case History of Federal Motor Vehicle Safety Standard 208: Occupant Crash Protection (GPO, 1979). 
Gregory was baffled by the public's attitude toward Standard 121. The purposes of Standard 121 seemed to merit strong popular support. Air brakes were not designed to protect motorists from their own folly, after all, but from the folly of others. But Gregory reported to Congress that "despite editorials fairly late in the game, [he] could feel practically no public interest" in the matter. ${ }^{63}$ Lack of public support, however, was to be the least of Standard 121's troubles.

Standard 121 was issued in supposedly "final" form on February 19, 1971. It set forth various performance standards for the braking systems of trucks, buses, and trailers, including stopping distances at specified speeds on wet and dry surfaces (for example, 245 feet at 60 miles per hour on a dry surface), and a requirement that vehicles stop within a 12 foot wide lane without more than momentarily locking any wheel. The standard's effective date was January 1, 1973.

While the regulated industries opposed many aspects of the rule, they objected most vociferously to the standard's controversial anti-lock requirement. The standard contemplated (but did not require) the use of state of the art electronic computer modules that would sense impending wheel lock-up and automatically adjust the air pressure in the brake chamber to maintain the wheels' rolling action. Eleven vehicle manufacturers, ten brake component suppliers, and six operator groups filed petitions for reconsideration. Their most common complaint was that the effective date could not be met, largely because more time was needed to develop and test anti-lock devices.

These and other complaints precipitated a seemingly endless cycle of revisions, new petitions for reconsideration, and new revisions. In 1974, for example, a year after the rule was supposed to have gone into effect, the agency issued an average of about one rulemaking notice on Standard 121 every two weeks. In turn, it received scores of requests for reconsideration. Indeed, between 1972 and 1975, the agency revised virtually every aspect of Standard $121 . .^{64}$

The flurry of notices, amendments, petitions, re-notices, and further amendments created a climate of confusion that only

${ }^{83}$ Regulatory Reform Hearings at 466 (cited in note 53).

64 For a general account of the agency's handling of Standard 121, see National Transportation Safety Board, Safety Effectiveness Evaluation of the National Highway Traffic Administration's Rulemaking Process, Vol 1: Case History of Federal Motor Vehicle Safety Standard 121: Air Brake Systems (GPO, 1979). 
strengthened the hand of Standard 121's opponents. The process seemed endless, and endlessly indecisive. The agency continued to revise the rule even after it had issued another "final" rule, had denied petitions to reopen the proceedings, and had been sued by the PACCAR corporation. The Transportation Secretary's office thought that the rulemaking process for Standard 121 reflected poorly on the agency. The endless revisions suggested that NHTSA was engaged in rulemaking by trial and error. ${ }^{65}$

Yet NHTSA's activities with respect to Standard 121 merely reflected the procedural imperatives that the courts had established for the construction of legally defensible rules. The major judicial review decisions of the late 1960 s and early $1970 \mathrm{~s}^{66}$ had instructed the agency to take questions of "practicability" seriously and to respond to the factual submissions of those who opposed the agency's proposals. Moreover, the agency could not modify and reissue its rules to take account of only manufacturers' objections. Another 1972 decision required it to provide all affected parties with an opportunity to comment on any significant modification of a rulemaking proposal. ${ }^{67}$ The agency could thus be overturned either for failing to respond effectively to the substance of rulemaking comments or for responding to the substance of comments without providing yet further procedures for further comment by other affected parties. The highly iterative rulemaking process for Standard 121 reflected the agency's prior experience in court.

Although the rulemaking process seemed endless, Standard 121 was the end of the line for Gregory. On February 26, 1976, President Ford publicly released his "Dear Jim" letter accepting Gregory's resignation "with sincere regret." The Administrator had privately submitted his notice of resignation a few days earlier. Although some opponents of Standard 121 had allegedly been spreading rumors of his impending resignation, most observers inside NHTSA and elsewhere were surprised by the decision. Gregory categorically denied that he had been asked to resign or had been fired. "[Y]ou get up one morning and you're worn out," Greg-

${ }_{65}^{65}$ The Secretary's view turned out to parallel that of the Ninth Circuit Court of Appeals. See PACCAR, Inc. $v$ NHTSA, 573 F2d 632, 636-39 (9th Cir 1979).

${ }^{66}$ In addition to the cases cited in note 25, see Automotive Parts \& Accessories Association v Boyd, 407 F2d 330 (DC Cir 1968).

${ }^{67}$ Wagner Electric Corp. v Volpe, 466 F2d 1013 (3d Cir 1972). 
ory told a New York Times reporter, "You think maybe it's time to lay this career to rest."68

\section{Finding Acceptance}

In his March 1 valedictory address to the House Subcommittee on Oversight and Investigations, Gregory indicated that NHTSA had found "public acceptance" in only one endeavor; public participation in defect proceedings was "excellent." The bull market in consumer complaints had continued. In October 1975, NHTSA established an experimental toll-free hotline in ten east coast states to disseminate information on defect investigations and to gather complaints. As one NHTSA observer later remarked, it was relatively easy to "set up a consumer hotline and have consumers do your work."

Meanwhile, the agency continued to tell Congress in budget submissions that the effect of recalls on vehicle safety "has not been established."70 NHTSA's own Advisory Council studied recall campaigns in 1976 and concluded that: "The question naturally arises-do the safety benefits of the program justify its cost? Curiously, no one knows. Indeed, the scarcity of hard facts and the abundance of unknown factors make any definitive evaluation of the defect-recall program very difficult."71 NHTSA nonetheless pressed forward with the recall program and the courts continued to approve its actions. In fiscal year 1976, the agency announced plans to transfer sixteen employees to the recall effort. At the same time, the staff in the principal divisions of the rulemaking office were reduced by fifteen employees. ${ }^{72}$ Bob Carter's grip was weakening.

\section{MVP (Read, Congress) vs. P \& P (Read, the President)}

Transportation Secretary Coleman and his staff were disgusted with the disarray at NHTSA. One senior DOT official during this period complained contemptuously that, "The problem is

${ }^{68}$ Diane Henry, Conflict Denied by Safety Chief, NY Times 30 (February 28, 1976).

${ }^{89}$ Personal interview with Brian O'Neill (June 11, 1987).

${ }^{30}$ Department of Transportation and Related Agencies Appropriations for Fiscal Year 1976, Hearings Before a Subcommittee of the House Appropriations Committee, 94th Cong, 1st Sess, Part 2200 (1976).

"1 Department of Transportation National Motor Vehicle Safety Advisory Council, Safety Defect Recall Campaigns (DOT, 1976).

${ }_{72}$ Department of Transportation and Related Agencies Appropriations for Fiscal Year 1976, Hearings Before a Subcommittee of the House Appropriations Committee, 94th Cong, 1st Sess Part 2 196, 199, 200 (1976). 
that they don't have any checks and balances down there and as a result everything they do becomes a cause célèbre." "'s The Secretary and his inner circle concluded that DOT would have to place NHTSA under tighter, more direct control if the rulemaking process was to have any semblance of order. Gregory's departure presented an ideal opportunity to establish the desired "checks and balances."

Coleman did not look far for a replacement. On April 21, 1976, he selected John W. Snow, the DOT Deputy Undersecretary, to succeed Gregory. ${ }^{74}$ Snow, age thirty-seven, had a Ph.D. in economics from the University of Virginia and a J.D. from George Washington University. He was an expert in economic regulation of the railroad, aviation, and motor carrier industries, and had joined the Department as Deputy Assistant General Counsel in 1972. By May 1, 1975, Snow had risen to the position of Deputy Undersecretary in which capacity he oversaw DOT's "regulatory reform" program.

Snow had only modest experience in safety regulation. His substantive involvement in automobile safety regulation had been limited to intermittent participation as a congressional liaison in a handful of high visibility issues, such as passive restraints and the ignition interlock. Snow's background, however, suggested his view of regulation. He taught cost-benefit analysis as a part-time lecturer on the economics faculty of the University of Maryland and represented DOT on the Domestic Council's Regulatory Review Group, the interagency task force established by President Ford to coordinate regulatory reform.

Safety partisans were appalled by Snow's appointment and bore down hard on his "regulatory philosophy" during the Senate Commerce Committee's nomination hearings on June 26, 1976. Much of the discussion focused on Snow's commitment to free market economics and to the appropriate use of cost-benefit analysis in the formulation of auto safety rules. Congress, of course, had repeatedly refused to enact legislation requiring NHTSA to justify its auto safety rules on the basis of cost-benefit comparisons..$^{75}$

From 1974 on, however, the executive branch increasingly pressured NHTSA to rationalize its standards on precisely those grounds. On November 27, 1974, President Ford signed Executive Order 11,821, which directed all executive branch departments to

\footnotetext{
${ }^{23}$ Quoted in Pruitt, 39 Pub Admin Rev at 367 (cited in note 9).

74 Alexander Hammer, People and Business, NY Times 53 (April 22, 1976).

${ }^{75}$ See, for example, Hearings on HR 13228 before the House Committee on Interstate and Foreign Commerce, 85th Cong, 2d Sess 269 (1966).
} 
prepare inflationary impact statements for major rulemaking proposals. ${ }^{76}$ The order was implemented by Office of Management and Budget Circular A-107, dated January 28, 1975, which directed each agency to develop procedures for evaluating rules in terms of quantified costs and benefits whenever possible. ${ }^{77}$

Following these orders, Secretary Coleman issued three "regulatory reform" policies on April 13, 1976.78 The first required DOT to assess the costs, benefits, and other effects of all of its rulemakings prior to issuance either in proposed or final form. The second policy required agencies within the Department to notify the Secretary thirty days before the proposed publication of any costly or controversial regulation. The third policy described the Department's recently implemented program of determining the actual costs and benefits of existing regulations.

Without more, Carter and his staff inside NHTSA might have ignored this blizzard of hortatory paperwork-that was certainly their inclination. Carter breezily admitted that as late as February 1976, NHTSA used cost-benefit analysis in only a "limited way.""9 MVP's tiny "cost and lead time" staff responsible for cost-benefit analysis (six persons in 1975) reflected the relatively low priority that MVP engineers gave to the effort. But in practical terms, Carter found it increasingly difficult to remain nonchalant. A new entity had begun to appear in the agency's rulemaking proceedings-the President's statutorily created Council on Wage and Price Stability (COWPS)-that was raising hell over NHTSA's treatment of costs and benefits in rulemaking. ${ }^{80}$

Following the promulgation of Executive Order 11,821, the Council had quickly decided to intervene in NHTSA's rulemaking proceedings on the airbag and the air brake. It filed comments that were highly critical of NHTSA's proposals. It filed similar submissions during 1975 on proposed amendments to Standard 105 (governing hydraulic brakes), to proposed cost information reporting

${ }^{76}$ Executive Order 11,821, Inflation Impact Statements, 3 CFR 926 (1971-75 comp), 39 Fed Reg 41501 (November 29, 1974).

77 Office of Management and Budget Circular A-107 (January 28, 1975).

7* Department of Transportation, Policies to Improve Analysis and Review of Regulations, 41 Fed Reg 16200-01 (April 16, 1976).

79 Federal Regulation and Regulatory Reform: Report by the Subcommittee on Oversight and Investigations of the House Committee on Interstate and Foreign Commerce, 94th Cong, 2d Sess 176 n 72 (1976).

so Id at $176-77$. 
requirements, and to the Uniform Tire Quality Grading Standard. ${ }^{81}$

MVP's cost and lead time staff was no match for the Council at cost-benefit analysis, and, because COWPS was the President's personal representative, Council submissions were hard even for Carter to ignore. Agency officials implied in testimony before Congress in 1976 that they were inclined to "defer" to the Council on matters of economic analysis. Indeed, under the Automotive Parts $^{82}$ decision, NHTSA was required to make a reasoned, thorough response to the detailed cost-benefit critiques offered by the Council's staff. Through the interaction of executive branch pressure and proceduralized judicial review, then, NHTSA was forced to adopt a cost-benefit methodology in setting standards, no matter what the 1966 Act said.

The agency's stalwart allies in Congress, especially on the oversight committees, were outraged that the Council could control NHTSA's rulemaking operations in this manner. But they were also ineffective in opposing the Council. Senator Hartke, for example, doggedly pursued the cost-benefit issue at Snow's nomination hearing. Hartke's particular grievance was not so much the Council's insinuation of cost-benefit considerations into rulemaking at NHTSA, but the Administrator-designate's own predilections on this issue. Hartke mounted a frontal attack on Snow's pre-hearing statement that "we should rely on marketplace incentives to the maximun extent appropriate." ${ }^{83}$ The nominee, however, was both unapologetic and unyielding.

Snow presumably was aware of the difficulty that Gregory had encountered only weeks before in hearings before Representative Moss's subcommittee on oversight and investigations. Gregory had rested the legitimacy of cost-benefit methodology at NHTSA on Executive Order 11,821 and had been lectured by Moss about the precedence of congressional statutes over presidential orders. ${ }^{84}$ Adroitly skirting those shoals, Snow made no mention of executive orders, Coleman's new regulatory policies, or the Council on Wage and Price Stability during his confirmation hearings. He explained that the use of cost-benefit comparisons was a judicially-imposed requirement. It derived from the courts' interpretation of the 1966

\footnotetext{
${ }^{81}$ Id at $177 \mathrm{n} 76$.

${ }^{82}$ Automotive Parts \& Accessories Association $v$ Boyd, 407 F2d 330.

${ }^{83}$ Snow Nomination Hearings at 68-69 (cited in note 20).

84 Regulatory Reform Hearings at $448-49$ (cited in note 53 ).
} 
Act's requirement that standards be "reasonable" and "practicable." Snow elaborated:

I think those words "reasonable" and "practicable" carry with them the connotation that the Administrator is to carefully analyze the alternatives available to him to advance the safety objective. In that analysis, looking at the benefits and looking at the costs, seem to me entirely appropriate.

In fact, as I read, I think it is the $H \& H$ Tire case in DOT, and $I$ have been reading a lot of cases-it is a brand new field for me-as I read the $H \& H$ Tire case, the $H \& H$ Tire case says that it is appropriate to use cost-benefit analysis to help inform the decision. And the failure to take into account effects of the standard on industry, the cost of the standard, can fatally-fatally affect the judicial review of the standards. ${ }^{85}$

Hartke's interrogation of Snow soon sputtered to an end.

Snow's appointment proved unstoppable; he was confirmed as Administrator on July 1, 1976. For safety partisans in Congress and elsewhere, however, there was a silver lining in the cloud created by Snow's appointment. Only three months remained until the Presidential election and public opinion polls revealed that Gerald Ford's administration was in trouble. With any luck, the safety partisans thought, Snow's tenure as Administrator would merely be a momentary lapse before reinforcements would arrive to reaffirm their conception of the original legislation. Snow, however, had other ideas.

As Snow scanned the regulatory landscape, his gaze fell upon Order 800-1, which had put MVP in control of the rulemaking process. He believed that the agency's proceedings on airbags and air brakes were not models of efficient administrative action and reasoned that something must be wrong with NHTSA's rulemaking process. By overhauling NHTSA's internal procedures for preparing rulemaking actions, Snow concluded, he could influence not only pending actions but, perhaps, future policy as well. For help in revising the 800-1 Order, Snow turned to Michael ("Why I Am Losing My Hair") Finkelstein and Frank Berndt.

Senior staff meetings were held to consider alternative rulemaking approaches. Over a winter weekend, Berndt, Finkelstein, and Snow hammered out the final revisions to the 800-1 Or-

85 Snow Nomination Hearings at 72 (cited in note 20). 
der, which was formally issued on February 2, $1977 . .^{86}$ Finkelstein later stated that the revised 800-1 Order had one overriding purpose-to free the Administrator from the "captivity" of MVP. ${ }^{87}$

The revised Order encompassed two complementary sets of reforms. The first was organizational; the Order redefined the role of engineers in relation to program analysts and attorneys. The second set of reforms was methodological; the Order emphasized the importance of cost-benefit considerations in standard-setting. Together, the reforms implemented an entirely new way of thinking about and conducting rulemaking at NHTSA.

The revised Order abolished MVP's supremacy in the standard-setting process. It eliminated NHTSA's "Evaluation Panel," which MVP had dominated under the original Order. In its stead, the revised Order implemented a seventeen step "flow chart procedure" in which rulemaking responsibilities were widely dispersed among engineers in MVP, policy and cost-benefit analysts in P \& $\mathrm{P}$, and attorneys in OCC. More importantly, under the new 800-1 Order, engineers could seek, but not force, consensus on proposed rules. While the original Order had empowered MVP unilaterally to resolve differences with other offices, the revised Order required that disputes be referred to the Administrator for resolution, and explicitly stated that "unless a delegation is granted in a specific area, the Administrator is responsible for establishing, amending, or revoking vehicle safety and fuel economy standards . . .."

In a memorandum accompanying the revised Order, ${ }^{88}$ Snow made clear that program analysts in P \& $\mathrm{P}$ and attorneys in OCC, especially the former, were to exercise independent judgment and to interrogate rulemaking engineers closely concerning the rationales for their proposals. The rulemaking process was intended to be intensely iterative. The revised Order envisioned that MVP would revise rulemaking support proposals in response to comments from $\mathrm{P} \& \mathrm{P}$ and OCC, and that amended proposals would be subject to further review and comment. The 800-1 Order thus internalized a painstaking process of notice and comment/renotice and recomment rulemaking, simply for formulation of proposals. Publication in the Federal Register would commence a similar process involving parties outside NHTSA.

\footnotetext{
${ }^{86}$ NHTSA, Rev Order 800-1 (February 2, 1977) (on file with authors).

${ }^{87}$ Personal interview with Michael M. Finkelstein (February 25, 1981).

${ }^{88}$ Memorandum from Administrator to Distribution (February 2, 1977) (on file with authors).
} 
Carter was enraged by the new procedures. He was especially incensed by the requirement of OCC concurrence on rulemaking support papers. Berndt would not sign off on rulemaking proposals until he was convinced, Carter later reported, that the supporting data were invulnerable to court challenge. Because it is impossible to eliminate the risk of losing in court, Carter believed that the revised 800-1 Order amounted to a pact not to issue rules at all. ${ }^{89}$

\section{The Illusion of 1966}

On February 13, 1977-less than two weeks after the issuance of the revised 800-1 Order-the new Secretary of Transportation, Brock Adams, announced that President Carter had chosen Joan Claybrook to head the agency. The contrast between Claybrook and Snow was stark. Claybrook had impressive credentials as a safety partisan. She was an ardent proponent of the airbag, and had unique experience in auto safety regulation. As a legislative assistant, Claybrook had participated in drafting the original Safety Act, and she later served as a Special Assistant to William Haddon, NHTSA's first administrator and the intellectual father of the new science of accidents upon which that Act had been predicated. She was a close associate of Ralph Nader, and in her subsequent position as President of Congress Watch, had continued to press for auto safety programs. Few persons were more knowledgeable or experienced in auto safety regulation or apparently more committed to the revolution of 1966 .

At times, Claybrook's testimony at her confirmation hearings seemed to directly refute John Snow's fundamental commitments. She emphasized, for example, that cost-benefit analysis was a very "imperfect" rulemaking tool, in part because benefits could not be fully measured and in part because its analytic methodology did not adequately take account of distributive effects. ${ }^{90}$ Moreover, Claybrook claimed that cost-benefit analysis was deficient because it was "linear, not intermodal," meaning that "it balances costs of a safety-improvement against its benefits, not against costly, frivolous items with little or no benefit value."91 Although her language was different, her sentiments mirrored those of Senator Abe Ribi-

* Personal interview with Robert L. Carter (June 9, 1987).

90 Nominations-March, Hearings Before the Senate Committee on Commerce, Joan Claybrook to be Administrator, NHTSA, 95th Cong, 1st Sess 10 (1977) ("Claybrook Nomination Hearings").

91 Id. 
coff, who called for the traffic safety hearings which led to the 1966 Act.

Claybrook also challenged Snow's reading of the case law. She told Congress that cost-benefit analysis was not a statutory requirement. A standard that cost more than the benefits it generated was lawful, she reasoned, even if issued without any analysis. In $H \& H$ Tire, Claybrook explained, "The court did not state that benefits of greater than unity must be shown to demonstrate 'economic practicability." "92 Moreover, Claybrook pointed out, the Sixth Circuit, in a footnote in Chrysler, had specifically found that Congress did not require the benefits of safety rules to exceed their costs. ${ }^{93}$ Some of Claybrook's statements seemed to preview a return to the heyday of MVP power. Although defect modifications and recalls were "very important," Claybrook testified, they were "not as fundamental" as the promulgation and enforcement of standards. ${ }^{94}$ Bob Carter, rejoice!

Now it was the industry's turn to be horrified. S. L. Terry, Vice President for Consumer Affairs at Chrysler, described the prospects of Claybrook's appointment as "appalling." "She has always been against the industry," he said in remarks to the press. "It certainly does not seem to be an even handed appointment. I would not expect that the Department of Transportation would appoint an auto executive, but likewise I also wouldn't expect the appointment of an industry critic or a Nader supporter." ${ }^{\text {96 }}$

\section{A. A Power Lunch}

Claybrook had been making plans to take command of NHTSA even before her nomination was formally announced. In January 1977, she had invited Frank Berndt to lunch at a restaurant on Capitol Hill. Their discussion set the tone for some of Claybrook's early moves and innovations as Administrator. ${ }^{97}$

Claybrook valued Berndt's advice, as her luncheon invitation implied. Both were lawyers and, to a significant extent, both spoke the same language. They viewed regulation in win-lose terms and expected to be involved in heated contests with the industry.

92 Id at 9 .

${ }^{93}$ Id.; Chrysler Corp. v DOT, 472 F2d at 672 n. 6.

* Claybrook Nomination Hearings at 13.

95 Ernest Holsendolph, Lobbyist for Nader to Head Safety Unit, NY Times 12 (March 19, 1977).

96 Id.

${ }_{97}$ Personal interview with Frank Berndt (June 2, 1987). 
Berndt's actions in court, moreover, had produced tangible results. The recall program was an unqualified legal success. NHTSA was winning every recall case and the per se defect theory had given NHTSA great leverage in dealing with the manufacturers-leverage now at Claybrook's disposal. NHTSA could impose significant costs and reputational damage on recalcitrant manufacturers without a major expenditure of scarce agency resources. "I have placed a powerful weapon in the Administrator's hands," Berndt later remarked, "and she's not afraid to use it."

Claybrook had a number of topics on her mind that day, including the internal divisions among the agency's staff chronicled by GAO in 1974. Claybrook knew that the conflict persisted. As the luncheon conversation wore on, she posed a question that Frank Berndt had been dwelling on for years: what should be done with Robert Lee Carter? Claybrook knew that Berndt's success on recalls had come without much support from Bob Carter. She reportedly believed that MVP's operation of the Office of Defects Investigation had been a disaster. In addition, Carter had made a mess of things on the rulemaking side of the house. The principal catastrophes-the Chrysler decision, the Standard 121 debacle, and the interlock episode-had occurred on Carter's watch. All were strategically debilitating and politically embarrassing, as Claybrook well understood. The agency could not afford similar reversals in the future.

When Claybrook asked about Carter, Berndt had a ready answer. He responded that MVP had acquired too much power under Carter and should therefore be dismantled. Enforcement activities, particularly the recall program, should be consolidated in a separate unit, equal in stature to the rulemaking program, but reporting to different management. Rulemaking should also be more effectively supervised and focused. These suggestions had an explicit or implicit corollary: the checks and balances embodied in the revised 800-1 Order should be retained, whatever Claybrook's views on the propriety of cost-benefit analysis.

Claybrook did not take immediate action on Berndt's grand design, but within weeks of her arrival she moved to enhance OCC's control over the recall program. She established a special task force, composed wholly of lawyers, to clear out pending cases. She placed Berndt in charge. Results quickly followed. NHTSA recalled over twelve million vehicles in 1977 , up from three million

${ }^{98}$ Personal interview with Frank Berndt (February 12, 1980). 
the year before. In 1978, the number totalled over nine million vehicles. ${ }^{99}$ NHTSA was recalling more vehicles than were coming off the production lines. ${ }^{100}$

Tensions between Claybrook and Carter arose immediately and mounted steadily. One senior agency official noted that there was a "negative personal chemistry" between them. ${ }^{101}$ Both had strong personalities and clashes were inevitable. Carter obviously did not share Claybrook's enthusiasm for confrontation by recall. On one occasion, for example, he discreetly negotiated a settlement with a manufacturer over a suspected defect. The manufacturer agreed to fix the problem promptly, provided that it could do so outside the glare of a high visibility recall campaign. Claybrook was enraged over the deal that Carter had struck, and "chewed him up one side and down the other."102 Claybrook was keeping score with the industry over recalls. Carter had forfeited agency points.

Claybrook, moreover, was her own associate administrator for rulemaking. She worked long hours, enjoyed the detail of close work, and was disinclined to delegate major decisions to Carter. Besides, the decisionmaking forum for the agency's most important initiatives-Standards 208 and 121 -had by this time largely shifted to Congress and the courts. The former legislative aid and director of Nader's congressional project did not need Carter's help in finding her way around the Hill. Moreover, Carter's connections with safety constituencies outside the agency-which had so impressed Mannella-were no match for Claybrook's long-standing ties. As spring turned to summer, Carter grew even more frustrated with Claybrook's domination of programs. She ran the agency more like a project officer than an Administrator, he believed.

In the early winter of 1977 , Claybrook acted on Berndt's proposal to restructure NHTSA. Her reorganization took effect on January 1, 1978, less than a year after their luncheon conversa-

9 NHTSA, Safety Related Recall Campaigns for Motor Vehicles and Motor Vehicle Equipment, Including Tires, Dot H5-803-308 (1977 annual safety defect report); NHTSA, Safety Related Recall Campaigns for Motor Vehicles and Motor Vehicle Equipment, Including Tires, DOT H5-803-964 (1978 annual safety defect report).

100 U.S. passenger car production totalled 9.2 million vehicles in 1977. US Bureau of the Census, Statistical Abstract of the United States: 1985595 ( GPO, 1985). Recalls of domestic passenger vehicles totalled about 9.8 million that year. NHTSA, Safety Related Recall Campaigns for Motor Vehicles and Motor Vehicle Equipment, Including Tires, DOT HS803-308 (1977 annual safety defect report).

${ }^{201}$ Personal interview with Howard Dugoff (June 12, 1987).

${ }^{102}$ Personal interview with Robert L. Carter (June 9, 1987). 
tion. ${ }^{103}$ Its purpose, Claybrook announced, was to "simplify the agency's structure and to improve the quality of its decisionmaking process." 104 In fact, however, the new organizational chart was in some respects more complex than the old one. The principal feature of the reorganization, as Frank Berndt advocated, was the separation of standard-setting from enforcement and investigation. MVP was abolished. Two new staffs were established in its place: one reporting to an Associate Administrator for Rulemaking, the other to an Associate Administrator for Enforcement.

This, then, set the stage for personnel shifts that unmistakably told the story of the revised priorities at NHTSA. In March 1978, Michael M. Finkelstein, Snow's former right hand man and chief cost-benefit analyst, was named Associate Administrator for Rulemaking. His deputy, Barry Felrice (an alumnus of the Federal Highway Administration), took charge of P \& P. Berndt became Associate Administrator for Enforcement. (After setting up this new unit, he returned to his post as Chief Counsel.) Carter was named director of the agency's test facility in East Liberty, Ohio. James Hofferberth, Carter's principal rulemaking assistant, and Andrew (No Defect) Detrick, head of the ODI, accompanied Carter to NHTSA's version of Siberia.

\section{B. The New Religion}

These changes hardly silenced the discontented voices within NHTSA. Remember that only two years after the Claybrook reorganization, Finkelstein issued his February 1, 1980 ultimatum to the rulemaking staff. The new Associate Administrator for Rulemaking issued this memorandum in order to root out two misconceptions that, he believed, were at the heart of his staff's resentment of P \& P and OCC. Finkelstein called the misconceptions "the two principal myths in NHTSA" that arose every time OCC and $\mathrm{P} \& \mathrm{P}$ delayed a rulemaking action in order to obtain more information. ${ }^{105}$ The first concerned the Rulemaking Plan, which identified NHTSA's rulemaking priorities and had been issued with great fanfare in 1978. It was the long awaited progeny of the general Rulemaking Plan of October 1971. The second misconcep-

\footnotetext{
${ }^{103}$ National Highway Traffic Safety Administration, Organization and Delegation of Powers and Duties, 43 Fed Reg 8525 (March 2, 1978); NHTSA Reorganization Information (undated mimeo) (on file with authors).

sor Id.

105 Memorandum from Associate Administrator for Rulemaking to All Rulemaking Staff 2 (February 1, 1980) (on file with authors). See text at notes 13-16.
} 
tion dealt with Claybrook herself. Finkelstein described the myths as follows:

"Myth I"

"It is in the RULEMAKING PLAN: (capitalizing denotes an item demanding special reverence)."

"Myth II"

"JOAN wants it (see note above)."106

The rulemaking staff, Finkelstein observed, "believed that the invocation of either myth should be sufficient to terminate the thought processes in P \& P and OCC."107

Finkelstein proceeded to dethrone these false idols. He noted that the rulemaking process was "a rigorous search" for "the best approach to ameliorate a problem."108 In preparing rules, he stated, it was important for the rulemakers to consider as many sources of information and perspectives as possible. A regulation might be warranted, but then again, it might not, depending on the results of the analysis and the iterative effort to validate assumptions. Finkelstein reminded his staff that "[i]t is the RULEMAKING PROCESS that determines whether a regulation will be issued, not the fact that it is included in the rulemaking plan."109 His memorandum chided the engineers that they should be "overjoyed" if the lawyers or analysts found reason to kill a rule because that would spare the engineers a "never-ending" stream of petitions by the regulated parties. ${ }^{110}$

He dismissed the second myth even more curtly. Claybrook's exhortations should not be misinterpreted, Finkelstein cautioned. To be sure, the Administrator wanted rulemaking completed "as quickly as possible," but she also wanted "the most intelligent course of action followed." "111 Finkelstein elaborated:

I want to emphasize as strongly as I can that the rulemaking process is not a rubber stamp procedure designed to get out regulations that have been divined by Claybrook, Finkelstein, or anyone else. It is intended to produce reasonable solutions to real problems as a result of the work of a large number of professionals thinking creatively.12

\footnotetext{
${ }^{108}$ Id.

107 Id.

${ }^{108}$ Id.

${ }^{108}$ Id.

${ }^{110}$ Id.

111 Id.

${ }^{112}$ Id at 3-4.
} 
Agency rulemaking was governed by the $800-1$ Order, not by the personalities of individual officials. Myths I and II accordingly were "forbidden as heresies."113

When Finkelstein issued his memorandum in 1980, Claybrook's new religion of auto safety was not producing a flood of important new rules. The first two years of her administration were devoted largely to Standard 208 and to the promulgation of fuel economy rules, a task that Claybrook's deputy later characterized as "terribly diverting."114 When the Administrator sought to press forward on other proposals in the second half of her term, she learned about the difficulties of assigning an offensive mission to a defensive team. The checks and balances of the rulemaking process, coupled with the agency's responsibility to consider the impact of its rules on the economy, the environment, small businesses, and urban communities, prevented it from preparing and issuing rules expeditiously.

Not until the very end of her administration was Claybrook able to issue in final form many of the proposals that had been pending since her arrival. By then, however, times had changed. The Reagan Administration had appointed new NHTSA leaders who simply revoked Claybrook's eleventh hour rules before they could take effect. They similarly dropped many pending proposals. ${ }^{115}$ A strong pro-safety administration spent four years generating only one significant rulemaking product, the revised Standard 208.

These difficulties had, of course, not beset the recall program. The Office of Plans and Programs occasionally urged the agency to subject recalls to cost-benefit analysis, but that proposal made little headway either during Claybrook's administration or thereafter. Berndt brushed aside the proposal as unworthy of serious consideration. Economists simply did not understand the law, he later explained. ${ }^{116}$

113 Id at 3.

11 Personal interview with Howard Dugoff (June 12, 1987).

115 NHTSA Oversight, Hearings Before the Subcommittee on Surface Transportation of the Senate Committee on Commerce, 97th Cong, 2d Sess 50-53 (1982) (statement of Clarence Ditlow, Director, Center for Auto Safety) (during the first sixteen months of the Reagan Administration, NHTSA rescinded or relaxed existing rules or terminated pending rulemaking in nineteen instances, and proposed similar actions in twenty-one instances).

116 Personal interview with Frank Berndt (June 4, 1987). 


\section{The Interaction of Legal and Bureaucratic Culture}

Berndt's comment about understanding the law is, in our view, a fitting epitaph for NHTSA's rulemaking efforts in the 1970s. Over the course of that decade, the law steadily reshaped the agency's internal organization and procedures. "Proceduralized" judicial review for rationality, combined with the demands of executive orders from three presidents, pressed NHTSA relentlessly toward the defensive, checks and balances internal procedure for proposing and acting on rulemakings. The agency, as a matter of formal internal procedure, began to litigate with itself. Losses in court stymied, embarrassed, and ultimately delegitimated the efforts of the principal proponents of aggressive rulemaking. Meanwhile, the recall program's legal burdens were progressively relaxed. The legal successes of the enforcement personnel, particularly Frank Berndt and OCC, lifted them to successively higher plateaus of power within the agency.

The hallmarks of internal development at NHTSA during the 1970 s were redeployment of personnel from rulemaking to enforcement, restructuring of lines of authority in favor of the recall effort, and increased use of complex internal procedures that emphasized the cautionary propensity of lawyers and economists. Those developments were undeniably shaped by factors other than the external legal culture. Public demand was the moving force behind the recall effort. Professional biases, bureaucratic ambitions, fiscal constraints, personality conflicts, and simple chance all clearly shaped the agency's structure, processes, and behavior. Yet, we are struck by the degree to which the judiciary's legitimation or delegitimation of NHTSA's efforts channelled the currents and crosscurrents of other influences into a stream of ideas and arguments and, ultimately, of internal processes and personnel decisions that shifted NHTSA away from the vision of 1966. That vision was, after all, not without staunch, talented, and powerful defenders. By all accounts, Bob Carter was technically well-qualified, a tough competitor in the bureaucratic trenches, and politically astute enough to build a solid network of external supporters. His staff of safety engineers was committed to the rulemaking effort. Moreover, the congressional oversight committees constantly urged the agency to get the rulemaking process moving. Had the courts ratified Carter's efforts in Chrysler and in other crucial cases of the early 1970s, while demanding that recalls be justified by demonstrable effects on safety, Joan Claybrook might well have had her winter luncheon with Bob Carter rather than Frank Berndt. 
Or, to take another example, John Snow and Bill Coleman were committed to implementing the Nixon-Ford policy of thorough assessment of the economic impact of regulations. But NHTSA's engineering staff, the relevant congressional committees, and Administrator Claybrook were not. As a result, NHTSA established procedures that scrutinized its rulemaking proposals in terms of their economic costs, benefits, and alternatives. The adoption of these procedures was not a function of top-down executive control; most other agencies found President Carter's regulatory review machinery to be a modest irritation, not a binding constraint. ${ }^{117}$ This defensive posture was made necessary by legal requirements. NHTSA felt compelled to explain to reviewing courts why the cost-benefit criticisms of COWPS, and the cost, lead time and "real world" effects arguments of manufacturers (and others) did not undermine the "reasonableness" or "practicability" of the agency's motor vehicle standards.

Much that went on inside NHTSA during the 1970s was unrelated to the biases of American legal culture. Nevertheless, the NHTSA that entered the new decade was powerfully shaped by the demands and the differential supports of the law.

${ }^{117}$ Christopher C. DeMuth, Constraining Regulatory Costs - Part I: The White House Review Programs, 4 Regulation 13, 17-18 (Jan/Feb 1980); and Christopher C. Demuth, Constraining Regulatory Costs - Part II: The Regulatory Budget, 4 Regulation 29 (March/April 1980). 
